\title{
A Descriptive Analysis of Doctoral Studies in Spain: Recent Changes
}

\author{
Jiménez Ramírez, Magdalena ${ }^{a}$ \\ ${ }^{a}$ Universidad de Granada
}

\begin{abstract}
The adaptation of Doctoral studies to the European Higher Education Area has involved a complex regulatory change in Spain, with the aim of harmonizing this stage of training with European guidelines. Royal Decree 99/2011 established a new organizational structure for the Doctorate and sets out the guidelines, conditions and procedures that are to regulate the new Doctoral studies. In this paper we describe some of the most significant changes, including, among others, the novelty of the creation of Doctoral Schools, and we likewise present a succinct descriptive overview of some data resulting from the implementation of the regulations on the configuration and putting into practice of the new Doctoral studies. We conclude that these transformations are complex at the levels of management, organization and operation, although they have involved a move towards training that qualifies candidates in research competencies within a setting of internationalization and European mobility.
\end{abstract}

Keywords: doctoral regulations; Doctoral Schools; European convergence; research competency; official statistical data. 


\section{Introduction}

The continuous regulatory changes that have taken place in Spain to develop Doctoral studies in accordance with the European Higher Education Area (EHEA), have led to a viewpoint tending to consolidate the regulatory changes required in order to converge with European guidelines for the Doctorate. This degree has the important role of relating the EHEA with the European Research Area as the basis for the construction of a society of knowledge, where research must be a distinctive element in doctoral and post-doctoral training (Fidalgo and Sánchez, 2007), permitting international mobility for the research training of doctoral candidates, and involving international appeal for research and the interchange of research knowledge.

The Bologna Declaration (1999) established two cycles of university education - first degree and post-graduate study - where the Doctorate was not initially contemplated as a fundamental objective (Castro et al., 2010), but merely formed part of the post-graduate cycle with more extensive training, but no separate identity. This structure was later completed with the Doctorate as third cycle (Berlin Declaration, 2003), laying emphasis on "the importance of research, research training and the promotion of interdisciplinarity, maintaining and improving the quality of higher education and improving the competitiveness of European higher education" (Berlin Declaration, 2003: 5), defining it as the first stage of a research career.

Successive communiqués (Berlin, 2003; Bergen, 2005; London, 2007; Leuven, 2009; Budapest-Vienna, 2010; Bucharest, 2012) have served to move towards the harmonization of doctoral guidelines at a European level (see http://eees.universia.es/documentos/reuniones-ministros-educacion-superior-europea/), in which the European Ministers responsible for Higher Education have defined the basic conditions for the Doctorate in the knowledge society. Likewise, the European University Association (2003, 2005, 2007) (see http://www.ehea.info/) has contributed to this definition through several studies and reports specifying recommendations for Doctoral Programmes.

As a member of these international areas, Spain has approved reforms to university legislation in order to establish principles for the Doctorate convergent with Europe. Spanish universities have designed a training model which places the doctoral candidate at the centre of research in $\mathrm{R} \& \mathrm{D}$ projects, thus providing quality, innovation, mobility and internationalization for trainee researchers (European Commission, 2015). These reforms must set up links for collaboration between the universities' Doctoral Programmes and business and industry, in which Doctoral Schools are to play a fundamental role. These modifications of the doctoral stage represent "methodical training in research in an 
interdisciplinary, cooperative and international setting" (Nebot, 2009: 12), where the Doctorate is endorsed as "the distinctive and exclusive trademark of the research university" (Nebot, 2009: 12).

The basic aims of this paper are to describe some of the characteristics of the new Doctoral studies, to explain the novelty of the creation of the Doctoral Schools and their attributed functions, and to provide some official statistical data on the implementation of Doctoral studies in Spain.

\section{Organizational structure of the Doctorate in Spain: the trend towards Europe.}

One of the aims of the EHEA is to set up a network of research training to allow the development of joint quality actions in a context of internationalization, reshaping Doctoral studies. The Doctorate is the highest academic degree and fulfils a key role in establishing a link between teaching and research, in addition to being a basic instrument of connection between the university and society (Castro et al., 2010). The achievement of this aim has involved a complex administrative and bureaucratic transformation, sometimes called a tortuous process, inasmuch as four different regulations have been approved for the Doctorate (González, 2009).

Doctoral studies are regulated by Royal Decree 99/2011, which lays down requirements to be specified in the universities' statutes. It defines the Doctorate as "the third cycle of official university study, leading to the acquisition of the competencies and skills related to scientific research of quality" (Roya Decree 99/2011, art. 2.1). According to Benito et al. (2014), in the present state of the knowledge society, Doctors qualified in scientific, research and technological production represent a fundamental value for placement in the productive sector. Accordingly, the law sets out guidelines in this direction, designed to train researchers in universities for them to create qualified training capital and transfer of knowledge. One of the most important characteristics is the setting up of Doctoral Schools and the modification of the present Doctoral Programmes.

\subsection{Doctoral Schools}

The most important novelty of the new regulations is the creation of Doctoral Schools. These are understood as a body that manages and organizes research and the offer of activities inherent to the setting up and development of the Doctorate in one or several fields of knowledge or with an interdisciplinary character (RD 99/2011, art. 2.4). As a specific structure of doctoral training, the School is an independent unit responsible for research, with leadership in its structure to organize and manage the offer of activities 
inherent to scientific research training in a field of knowledge (Roya Decree 99/2011, art. 9).

Collaboration must be established with other Spanish or international bodies, schools, institutions and entities with R\&D activities. Likewise, the various training aspects of the doctoral candidate must be developed and the procedures and lines of research for the development of doctoral theses must be set out, all taking into consideration the importance of Doctors to contribute socially to a sustainable economy made possible by the transfer of research results. The priority is that students in research training "have to lead and cooperate in the transfer of knowledge towards the welfare of society (Royal Decree, p. 13.911). Each Doctoral School is governed by its corresponding Academic and Management Committees, and its activities can be organized around one or more specialized or interdisciplinary fields.

\subsection{Doctoral Programmes}

The new law (RD 99/2011) also establishes changes in the organization of Doctoral Programmes. The former departmental and/or interdepartmental and/or interdisciplinary structure, which made possible different research lines around a joint Doctorate and presenting Doctoral Programmes to obtain the Mention of Quality (ANECA, 2009), now gives way to a structure which specifies much more the content of Doctoral Programmes depending on the Doctoral Schools. In addition, Doctoral Programmes must now be verified by the Universities Council, recognised (Annexe II, RD 99/2011) by ANECA evaluation, and have a Coordinator, who must fulfill the requirements of having supervised at least two doctoral theses and holding at least two six-year research awards.

The law (RD 99/2011, art. 2.2) defines Doctoral Programmes as "a set of activities leading to the acquisition of the competencies and skills necessary to obtain the degree of Doctor," in which the research training of the candidates is key, and not restricted to training for university teaching. The aim is to link the candidate's research training and their incorporation into the job market, given the need to redirect doctoral students' professional aspirations, with the collaboration of "external allies", such as institutions and bodies with R\&D strategies, thus creating potentialities for research.

\section{Statistical data}

We here describe some statistical data on the implementation of RD 99/2011, based on the available university statistics (MECD, 2015; Hernández \& Pérez, 2015; University Register of Catalogue of Degrees, RUCT). Regarding the Doctoral Schools, there are 1042 
university centres distributed over a total of 82 universities (Hernández \& Pérez, 2015). Not all universities have founded Doctoral Schools. Those that have been set up are 55 Doctoral Schools, 1 School for Doctoral and Postgraduate Studies, 1 School for Postgraduate and Doctorate, 2 Schools of Master and Doctorate, 1 International Postgraduate Centre, and 1 School of Doctorate and Research, all belonging to (private and public) attendance universities (RUCT).

Regarding the denominations, Doctoral School has been chosen for the majority, only 6 universities have brought together Master and Doctorate, or Postgraduate, including doctoral training in the latter, 16 universities include the adjective "international" in the name of the school, and one other university chose the name "International Postgraduate Centre." Most of the Doctoral Schools have been set up in public universities (48), although there are also some private universities (13). The trend has also been to set up one Doctoral School per university, with the exception of the University of Granada, which has created three Doctoral Schools.

In distribution by Autonomous Community, Andalusia has the most with 13 Doctoral Schools, Catalonia has 10 and 1 School for Postgraduate and Doctorate, the Community of Madrid has 8 and 1 School of Doctorate and Research, the Community of Valencia has 6, Castile and Leon has 5, the Region of Murcia and Galicia have 3 each, the Foral Community of Navarre has 2 and the Canary Islands have 1 Doctoral School and 1 School for Doctoral and Postgraduate Studies, the remaining Autonomous Communities have 1 Doctoral School each, except for Extremadura, for which there are no records, and the Principality of Asturias, although the latter has an International Postgraduate Centre. Most of the Doctoral Schools are in public universities. There are Doctoral Schools in private universities in Catalonia (4 Doctoral Schools and 1 School for Postgraduate and Doctorate), Madrid (3), Andalusia (2), and Castile and Leon, the Community of Valencia and the Region of Murcia have 1 Doctoral School each.

The Doctoral Schools of each university offer different Doctoral Programmes evaluated and verified by the ANECA. The RUCT records a total of 1267 Doctoral Programmes, of which 659 are Programmes adapted to the EHEA and are at present regulated by RD 99/2011. The remaining 608 Programmes are Masters degrees and Official Doctoral Programmes and Official University Postgraduate Degrees regulated by the previous legislation and due to be discontinued. Although the Doctoral Schools are registered with the RUCT, not all their Doctoral Programmes have been registered, although their web pages show that they do offer Doctoral Programmes adapted to the new regulations.

It should also be noted that of all the Doctoral Programmes regulated by RD 99/2011 and registered in the RUCT, only a few are shared by more than one university. The Doctoral Programmes can be grouped under their respective Doctoral Schools, as in the University 
of Granada, for example, or they can be classified by fields of knowledge (Arts and Humanities, Health Sciences, Natural Sciences, Engineering and Architecture, Social and Legal Sciences). Depending on the university, Doctoral Programmes can also be offered that deal exclusively with a single theme, such as at the University of Cadiz, whose International Doctoral School on Marine Studies (EIDEMAR) has Doctoral Programmes specifically on this question.

Concerning the number of students registered for Doctoral Studies, the preliminary statistical data of the MECD for 2014-2015 on university students show that, according to the regulations of RD 99/2011, the total number of students registered is 28,546. However, we should specify that there are still students registered for Doctoral studies under the previous legislation that have yet to conclude their studies. Hernández \& Pérez (2015) calculate that there were 85,390 students registered for the year 2013-2014, representing $5.69 \%$ of the total of students registered in 1st and 2nd cycles, First Degree, Masters, Short Courses and Doctorate, mainly in public universities.

Despite the fact that Third Cycle students are a minority percentage, the data indicate that an increase is taking place in the number of students registered in all Spanish universities, both public and private. Specifically, the 74,648 Third Cycle students during the 2008-2009 academic year have grown to 88,732 Doctoral students for the year 2013-2014 (Hernández $\&$ Pérez, 2015). According to the numbers of students registered under the regulations of RD 99/2011, there is a rather equal split between male $(50.20 \%)$ and female $(49.80 \%)$ students. However, differences are to be found among students registered according to branches of knowledge and sex.

Regarding student registration by branches of knowledge, the Social and Legal Sciences have the highest numbers (26.72\%), followed by Health Sciences (22.99\%), Engineering and Architecture (18.23\%), Arts and Humanities (17.82\%) and Natural Sciences (14.24\%). Female students are more common in Health Sciences (14.52\% vs. 8.46\%), Social and Legal Sciences (13.53\% vs. 13.18\%) and Arts and Humanities (9.56\% vs. 8.26\%), although the differences in the last two branches are slight. On the other hand, male students are more common in Engineering and Architecture (12.79\% vs. 5.44\%) and Natural Sciences $(7.50 \%$ vs. $6.73 \%)$. The most notable differences, therefore, by sex and branch of knowledge are found in the Health Sciences, where female students predominate, and in Engineering and Architecture, with a more significant presence of male students.

These data show that, despite the democratic consolidation of women's gaining access to university education, their presence continues to be unequal in some branches of knowledge and in the categories of research thought to entail greater prestige and social recognition, thus leading to an unfavourable gender bias in women's scientific careers (Villarroya et al., 2008). This question also occurs in the access to Doctoral Studies and the differentiation 
between the branches of knowledge chosen by male and female students, and, even, in the percentage of women with management positions, which is still low (Grifoll, 2009).

\section{Conclusions}

The entire process begun in Spain to adapt to the EHEA has involved legislative changes that have yet to allow the new guidelines in management and organization to come into effect, and to consolidate approaches more related to an international, convergent orientation for Doctoral studies (Jiménez \& Sevilla, 2016). There has been a shift from a view centred on university Departments as those responsible for teaching and research, from the appraisal of interdepartmental relations and the proximity of areas of knowledge, to the consideration of the affinity of lines of research for the organization of the different Doctoral Programmes. Likewise, there has been a move away from the goal of postgraduate training linked to university teaching, to establish that research must be the central nucleus for the development of a research career with a view to incorporation into the productive sector of society (Benito et al., 2014).

In order for this shift in doctoral training to take place it is key that actions are carried out by the State, the Administration, institutions and the business sector to link the doctoral candidate with projects of research, development and innovation that qualify the candidate in the acquisition of skills, that allow internationalization and mobility in a European setting, in order to create transfer of knowledge from the university into society, and that contribute to the search for the employability of Doctors, while at the same time increasing public and private investment in R\&D (Hernández \& Pérez, 2015) and the public funding of the university (Gutiérrez-Solana, 2010).

\section{References}

ANECA (2009). XI Foro ANECA. Madrid: ANECA.

Benito, M., Gil, P. \& Romera, R. (2014). El empleo de los doctores en España y su relación con la $I+D+i$ y los estudios de doctorado. Gran Canaria: CRUE.

Castro, A., Guillén-Riquelme, A., Quevedo-Blasco, R., Ramiro, Mª T., Bermúdez, Mª P. \& Buela-Casal, G. (2010). Las Escuelas Doctorales: evolución histórica, características y aspectos relevantes para su consolidación en España. Aula Abierta, 38(2), 17-28.

European Commission (2015). The European Higher Education Area in 2015. Luxembourg: European Union.

Fidalgo, R. \& Sánchez, J. (2007). Las directrices del EEES en el marco legislativo del sistema universitario español. Aula Abierta, 25(1-2), 35-48. 
González, J. (2009). Ordenación de las enseñanzas universitarias. In J. González, Comentarios a la Ley Orgánica de Universidades (pp. 637-694). Navarra: Civitas.

Gutiérrez-Solana, F. (2010). Políticas universitarias para una década: problemas y oportunidades. La Cuestión Universitaria, 6, 4-11.

Grifoll, J. (2009). La educación de posgrado (Doctorado) desde la perspectiva del estudiante. En ANECA, IX Foro ANECA (pp. 79-88). Madrid: ANECA.

Hernández, J. \& Pérez, J.A. (2015). La Universidad Española en cifras. Madrid: CRUE.

Jiménez, M. \& Sevilla, D. (2016). Doctoral Studies in Spain. In C. Cappa \& D. Palomba (Comps.), Doctoral Studies in Europe. Roma: Aracne Editrice. (En prensa).

Ministerio de Educación, Cultura y Deporte (2015). Datos de estadísticas universitarias, curso 2014-2015. Madrid: MECD.

Nebot, I.J. (2009). Introducción. El desafío de los programas de doctorado. En ANECA, IX Foro ANECA (pp. 11-20). Madrid: ANECA.

RD 99/2011, (January, 28), regulating official Doctoral courses. BOE, 35, February, 10, 13,909-13,926.

Villarroya, A., Barrios, M., Borrego, À. \& Frías, A. (2008). La obtención del Doctorado en España: un análisis de género. In Actas del I Congreso Internacional sobre sesgo de género en la evaluación de la calidad académica (pp. 159-168). Barcelona: UAB. 